\title{
The spatial ecology of juvenile loggerhead turtles (Caretta caretta) in the Indian Ocean sheds light on the "lost years" mystery
}

\author{
Dalleau Mayeul $^{1,2,3,4, *}$, Benhamou Simon ${ }^{2}$, Sudre Joel ${ }^{5}$, Ciccione Stephane ${ }^{3}$, Bourjea Jerome ${ }^{4}$
}

${ }^{1}$ Univ La Reunion, UMR Espace Dev, St Denis 97715 9, Reunion.

${ }^{2}$ CNRS, Ctr Ecol Fonct \& Evolut, F-34293 Montpellier 5, France.

${ }^{3}$ Kelonia, Observ Tortues Marines La Reunion, St Leu 97436, Reunion.

4 IFREMER, Le Port 97822, Reunion.

${ }^{5}$ CNRS, Lab Etud Geophys \& Oceanog Spatiale, F-31401 Toulouse 9, France.

*Corresponding author : Mayeul Dalleau, email address : mdalleau@gmail.com

\begin{abstract}
:
While our understanding of the early oceanic developmental stage of sea turtles has improved markedly over recent decades, the spatial context for this life history stage remains unknown for Indian Ocean loggerhead turtle populations. To address this gap in our knowledge, 18 juvenile loggerheads were satellite tracked from Reunion Island (21.2A degrees S, 55.3A degrees E) between 2007 and 2011. Nine turtles swam north toward Oman (20.5A degrees N, 58.8A degrees E), where one of the world's largest rookeries of loggerheads is located. Three individuals traveled south toward South Africa and Madagascar, countries that also host loggerhead nesting grounds. Fourteen of the transmitters relayed diving profiles. A dichotomy between diurnal and nocturnal diving behavior was observed with a larger number of shorter dives occurring during the day. Diving behavior also differed according to movement behavior as individuals spent more time in subsurface waters (between 10 and $20 \mathrm{~m}$ ) during transit phases. The study provides an understanding of the oceanic movement behavior of juvenile loggerheads in the Indian Ocean that suggests the existence of an atypical trans-equatorial developmental cycle for the species at the ocean basin scale in the Indian Ocean. These results address a significant gap in the understanding of loggerhead oceanic movements and may help with the conservation of the species.
\end{abstract}

Introduction

Loggerhead sea turtles (Caretta caretta) have a global distribution throughout tropical and warm temperate waters, and the species is classified as endangered in the IUCN Red List (IUCN 2012). A striking feature of the life history of loggerheads is the large-scale, oceanic basin, development cycle. After entering the sea, hatchlings execute an intense, but brief, swimming phase known as the "swimming frenzy" (Wyneken and Salmon 1992). They then enter a neritic transitional phase lasting from a few days to a few months (Musick and Limpus 1997), after which they enter the oceanic zone. Juvenile and subadult loggerheads remain in the 
open ocean for many years, a phase referred to as the juvenile oceanic stage (Bolten 2003), during which their movements are driven essentially by the oceanic currents (Carr 1986). This stage of the development cycle was first referred to as the "lost year" (Carr 1952; Carr 1986) and later as the "lost decade" (Musick and Limpus 1997) since it has long remained a stage of which little was known due to the difficulty of following the movements of hatchlings once they had departed the coastline. After this temporally variable oceanic stage (Bolten 2003), loggerhead juveniles return to neritic habitats before reaching sexual maturity (Bjorndal et al. 2000; Bolten 2003). It has been demonstrated, however, that some juveniles can frequent the oceanic environment until sexual maturity (McClellan and Read 2007; Mansfield et al. 2009; McClellan et al. 2010). Similarly, many adults also establish feeding ranges far removed from coastal zones (Hawkes et al. 2006; Hughes 2012). It has been suggested that these two strategies provide survival advantages. Whereas a neritic foraging strategy might be more energetically favorable for turtle development, an oceanic foraging strategy may reduce exposure to predation (Peckham et al. 2011).

In the North-Atlantic Ocean, the loggerhead development cycle is spread across the entire basin (Bolten 2003), with turtles drifting from the western Atlantic nesting sites to the islands of Azores, Madeira and Canary Islands (Putman et al. 2012; Scott et al. 2012). Similarly, in the Pacific Ocean, genetic studies have demonstrated that the development cycle occurs on an even greater scale, originating from breeding sites in Japan, Australia and New Caledonia, and reaching as far as the coasts of Baja California in Mexico (Bowen et al. 1995; Bowen and Karl 2007; Boyle et al. 2009).

Whilst genetic and oceanographic studies have provided a better understanding of large scale movement patterns of the loggerhead juvenile stage in the Atlantic and Pacific Oceans, information on their diving behavior remains scant. A diel diving behavior has been exhibited by loggerheads during the open sea juvenile stage (Godley et al. 2003; Polovina et 
al. 2004; Howell et al. 2010), with daytime dives being significantly shorter and more numerous than nighttime dives. Recently, Howell et al. (2010) showed that, in the North Pacific Ocean, oceanic juveniles spend $80 \%$ of the time, day and night, at very shallow (0$5 \mathrm{~m})$ depths $(90 \%$ in $0-15 \mathrm{~m})$. Moreover, this study revealed that the diving behavior was variable across meso-scale oceanic features, with turtles making deeper and longer dives when encountering more dynamic waters (Howell et al. 2010).

In the Indian Ocean, significant nesting sites for loggerheads are located at the edge of the western part of the basin in the northern and the southern hemispheres and on the northern coast of Western Australia (Baldwin et al. 2003; Halpin et al. 2009). Masirah Island (Sultanate of Oman; $20.5^{\circ} \mathrm{N}, 58.8^{\circ} \mathrm{E}$ ) in the North, is considered one of the world's largest nesting sites (ca. 30,000 nesters per year ; Ross and Barwani 1995; Ross 1998; Rees et al. 2010). South Africa $\left(27.1^{\circ} \mathrm{S}, 32.8^{\circ} \mathrm{E}\right)$, Mozambique $\left(26.3^{\circ} \mathrm{S}, 32.9^{\circ} \mathrm{E}\right)$ and Western Australia are also known to host important nesting populations (ca. 500-1000 nesters per year ; Hughes 2010; Nel et al. 2013; Baldwin et al. 2003). In the south-western coast of Madagascar $\left(23.8^{\circ} \mathrm{S}, 43.7^{\circ} \mathrm{E}\right)$, nesting events have also been reported, but nesting activity in this area is poorly documented and thought to be limited (Martel 2003; Rakotonirina 2011). Other minor nesting sites have also been identified in Yemen and Sri Lanka (Halpin et al. 2009).

Whereas recent studies have focused on the spatial dynamics of adult loggerheads in the western Indian Ocean (Oman: Rees et al. 2010; South Africa: Luschi et al. 2006), only one study focused on the juvenile stages (e.g. Hughes 1973), which produced few data on oceanic movements.

The main objective of our study was to document the foraging strategies of juveniles by determining the environmental conditions with which they were associated from their satellite-recorded large scale oceanic movements. Our study thus aimed to provide a better understanding of these oceanic movements and the diving behavior of juvenile loggerheads, 
so as to provide key information for the survival of this species, which is of major concern both in the Indian Ocean (Petersen et al. 2009) and worldwide (Lewison et al. 2004).

\section{METHODS}

\section{Study area and sea turtle tracking}

Late juvenile loggerheads are captured as bycatch by long-lining fishing boats from Reunion Island $\left(21.15^{\circ} \mathrm{S}, 55.27^{\circ} \mathrm{E}\right)$. These vessels operate in French and Madagascar exclusive economic zones (between $25^{\circ} \mathrm{S}$ and $16^{\circ} \mathrm{S}$, and $49^{\circ} \mathrm{E}$ and $57^{\circ} \mathrm{E}$; Online Resource 1 - Fig.1).

Following a collaboration protocol, fishermen declare to the official authorities (CROSS Réunion) any accidental captures of loggerheads for which on-board hook extraction is not possible. Individuals are then brought to 'Kélonia Sea Turtle Observatory and Care Centre' (www.kelonia.org) where they receive veterinary surgery for hook extraction and are placed in tanks at the care centre. General behavior and physiological parameters are regularly monitored.

A set of criteria has to be fulfilled before deciding that the animal has recovered sufficiently to be released: (1) the injuries have to be healed completely, (2) individuals must be able to ingest prey efficiently and regain body mass, (3) active swimming behavior must be resumed and (4) individuals must be free of anemia or infectious disease (confirmed through blood analysis). Between 2007 and 2011, a total of 56 individuals were brought to the care centre. Fourteen individuals (25\%) died following the operation. To date, 27 (48\%) have been released, of which 18 were fitted with Argos Platform Terminal Transmitters (PTTs). The mean \pm SD curved carapace length of individuals released with a satellite tag was $67.7 \pm 5.4$ $\mathrm{cm}(\mathrm{n}=18)$. 
We used four types of PTTs: A: TAM-4225, B: TAM-4325 and C: A-225 (Telonics, Inc., Mesa, Arizona), and D: SPOT-5 (Wildlife Computers, Inc., Bellevue, Washington). PTTs were attached on the second vertebral carapace scute with epoxy resin (Power-Fast and Pure2k; Powers Fasteners Inc., Wieringerwerf, Nederland). PTTs of types C and D were programmed to transmit data continuously whereas PTTs of types A and B transmission followed a duty cycle involving 24 hours "on" followed by 12 hours "off" to extend life expectancy. Turtles were released approximately $3 \mathrm{~km}$ off the west coast of Reunion Island $\left(21.15^{\circ} \mathrm{S}, 55.27^{\circ} \mathrm{E}\right)$ after periods of captivity ranging from 28 to 876 days (mean \pm SD : $277 \pm 209$ days; Table 1 ).

\section{Location and dive data acquisition}

The mean \pm SD lifetime of PTTs was $158 \pm 112$ days (maximum 401 days, type A: $168 \pm 53$, type B: $148 \pm 21$, type C: $40 \pm 17$, type D: $268 \pm 162$, see Table 1). Location data were filtered in two successive stages: (1) ad-hoc heuristic pre-filtering and (2) state-space model (SSM) were recorded: single dive parameters and integrated dive parameters. Single dive parameters corresponded to last dive duration and maximum depth. Integrated parameters corresponded to number of dives, average duration, maximum duration, maximum depth, underwater 
143 percentage and time-at-depth histograms. They were computed over a given timeframe of

144 either $12 \mathrm{~h}$ (types A and B) or $24 \mathrm{~h}$ (type C). Details of measured parameters and sampling 145 frequency for each type of device are provided in Table 2.

146 Types A and B were programmed to tabulate integrated dive data into 12-h periods 147 06:00-18:00 and 18:00-06:00 GMT+4 (roughly corresponding to daytime and night periods in 148 the study area). The depth bins for the time-at-depth distributions were $10 \mathrm{~m}$-width from 149 surface up to $60 \mathrm{~m}$, and $20 \mathrm{~m}$-width from $60 \mathrm{~m}$ to $120 \mathrm{~m}$. Two additional bins were used for 150 deepest dives: $120-160-\mathrm{m}$ and larger than $160 \mathrm{~m}$. Type $\mathrm{C}$ was programmed to tabulate dive data into 24 -h periods with 20 m-width depth bins from the surface down to $180 \mathrm{~m}$.

\section{Oceanic environment}

The following environmental parameters were extracted along the filtered tracks using linear temporal and bilinear spatial interpolation: (1) sea surface temperature (SST), (2) net primary production (NPP), (3) sea surface currents and total kinetic energy per water mass unit (TKE).

(1) Satellite-derived SST data were taken from the Moderate Resolution Imaging Spectroradiometer (MODIS), a major NASA EOS instrument aboard EOS-Aqua satellite (http://oceancolor.gsfc.nasa.gov; Savtchenko et al. 2004). Datasets are available daily with a spatial resolution of $4.63 \mathrm{~km}$.

(2) Ocean NPP data were downloaded from Oregon State University (http://www.science.oregonstate.edu/ocean.productivity/). NPP calculation is based on the Vertically Generalized Production Model (Behrenfeld and Falkowski 1997). Datasets used for NPP calculation include MODIS surface chlorophyll concentrations, sea surface temperature and photosynthetically active radiation. Datasets are available at 8-days interval with a spatial resolution of $9 \mathrm{~km}$. 
(3) The surface currents were extracted from the GEKCO database which provides a satellite surface current product on daily basis at quarter degree resolution with a global coverage from $82^{\circ} \mathrm{N}$ to $82^{\circ} \mathrm{S}$ (Sudre et al. 2013). These current estimates are the sum of geostrophic current (resulting from the balance between the horizontal pressure gradient and the Coriolis force) and Ekman transport (resulting from the balance between the frictional stress due to the wind and the Coriolis force). These data were used both to compute motor (water masses-related) movements from recorded (ground-related) tracks and TKE (TKE $=$ $1 / 2 \mathrm{~s}^{2}$ where $\mathrm{s}$ is the current speed; Howell et al. 2010).

\section{Movement behavior}

Turtles were divided into three groups based on latitude at last location: North (north of the equator), South (south of $30^{\circ} \mathrm{S}$ ) or Undetermined (all others), which were still in the vicinity of the released site when their PTTs stopped transmitting. Horizontal movements (hereafter simply refer to as movements) were classified as "oceanic transit" (OT), "coastal transit" (CT), "oceanic residency" (OR), or "coastal residency" (CR). Transit and resident phases were distinguished in terms of residence time (Barraquand and Benhamou 2008), which corresponds to a well-behaved extension of the first passage time, leading to a less noisy time series that therefore can be more easily segmented in different phases. Transit phases correspond to movements characterized by lowest residence times, which were assumed to occur in areas through which turtles were moving rapidly, whereas resident phases correspond to movements characterized by highest residence times, which were assumed to occur in concentrated-searching, food-rich areas. Because oceanic currents can have a major influence on sea turtles movements, we first computed the current-corrected tracks, corresponding to "motor" movements (i.e. performed with respect to water-masses) by subtracting the current effects to the ground-related (i.e. Argos recorded) tracks (see Girard et al. (2006) for details). 
Residence time was then computed, within a $200 \mathrm{~km}$-radius circle, as the sum of the first passage time within the circle and possibly of additional backward and forward time(s) spent in the circle, with due care that the time(s) spent outside the circle before re-entry was not larger than a given threshold. This was set at 10 days in the present study. The $200 \mathrm{~km}$ radius was chosen because habitat selection of juvenile loggerheads is known to occur at a scale of hundreds, rather than tens, of kilometres (Revelles et al. 2007). The limit of 10 days was set up to avoid irrelevant movement portions (further or prior to location) being encompassed within the residence time computation. The residence time series was segmented using the Lavielle (2005) procedure, with a maximum number of 10 segments and a minimum of 20 locations in a segment. Segments were assigned to either transit or resident phases, based on mean resident time over the segment, with higher residence times corresponding to the resident period. The whole procedure was repeated with radii of 100 and $300 \mathrm{~km}$, as well as with an unlimited time allowed outside the circle before re-entry so as to check that our results were not too sensitive to the choice of these parameters. No major differences were observed in the identification of the resident and transit phases. These phases, when taking place less than $100 \mathrm{~km}$ from any coastal area (continent or island) were considered coastal, and beyond $100 \mathrm{~km}$, oceanic.

\section{Diving behavior}

Based on distributions of dive depth and dive duration, we identified three categories of dives: shallow and short dives (Dss: depth $<30 \mathrm{~m}$, duration $<13 \mathrm{~min}$ ), shallow and long dives (Dsl: depth $<30 \mathrm{~m}$, duration $>13 \mathrm{~min}$ ) and deep and long dives (Ddl: depth $>30 \mathrm{~m}$, duration $>13 \mathrm{~min}$ ). Cut-offs of $13 \mathrm{~min}$ and $30 \mathrm{~m}$ were chosen as limits between classes based on dive depth and dive duration distributions (Fig. 1). When only dive duration was available (PTT type $\mathrm{C}$ ), dives were either assigned to long dives ( $\mathrm{Dl}$; duration $>13 \mathrm{~min}$ ) or to short and 
shallow dives (Dss; duration $<13$ min). The latter should have been considered simply as short dives, but it appeared that dives with duration inferior to 13 min were rarely deeper than $30 \mathrm{~m}(0.27 \%$, based on data from PTT types A and B). The dives that did not meet any of these criteria $(0.17 \%)$ were not assigned to any category.

\section{Computations and Statistical analyses}

223 All results are presented as median $\pm \mathrm{IQR}$. For comparison of diving and environmental data, we either used a Kruskal-Wallis test for multiple group comparison, a Wilcoxon signed-rank test for paired comparison between two groups or a Mann-Whitney $U$ test for unpaired comparison between two groups. When possible, exact P-values were computed. Most analyses were performed using $\mathrm{R}$ software (R Core Team, 2012). Current-correction and residence time analyses were performed using Pascal programs developed by the authors. Lavielle (2005) segmentation was performed using his Matlab script (http://www.math.upsud.fr/ lavielle/programs/dcpc.zip).

\section{RESULTS}

\section{Movement patterns}

The tracks of these 18 individuals are shown on Fig. 2. Nine turtles were assigned to the northern group (N1-N9) and four to the southern group (S1-S4). Northern turtles reached the latitude of Arabian Peninsula in the northern hemisphere while southern individuals traveled beyond the latitude of South Africa. The remaining five either remained in the vicinity of the release site $(\mathrm{X} 2-\mathrm{X} 4)$ or their transmitter stop transmitting shortly after deployment (X1 and

240 X5; Table 1). There were no significant differences between the average sizes of individuals per group (Kruskal-Wallis test, $\mathrm{H}_{2}=4.12, \mathrm{P}=0.13$ ). The total distanced travelled was 2,932 
$\mathrm{km} \pm 2,206 \mathrm{~km}(\mathrm{n}=18)$. The maximum straight distance travelled was 4,591 km (N5 reached

243 the coast of the Sultanate of Oman). Turtles from the northern and southern groups 244 respectively travelled $3,584 \pm 736 \mathrm{~km}(22.1 \pm 8.6 \mathrm{~km} /$ day, $\mathrm{n}=9)$ and 2,386 $\pm 857 \mathrm{~km}(10.6 \pm$ $24512.2 \mathrm{~km} /$ day, $\mathrm{n}=4)$ away from the release point. The other turtles travelled $671 \pm 505 \mathrm{~km}(6.8$ $246 \pm 26.7 \mathrm{~km} /$ day, $\mathrm{n}=5$ ). There were no significant differences between the groups in the 247 average daily straight-line distances travelled (Kruskal-Wallis test, $\mathrm{H}_{2}=1.44, \mathrm{P}=0.49$ ).

248 Neither was there any significant relationship between the size of the animals and the average 249 daily straight-line distance travelled (Spearman rank correlation, $\mathrm{r}_{\mathrm{s}}=0.04, \mathrm{n}=18, \mathrm{P}=0.97$ ).

The nine individuals of the northern group (N1-N9) displayed similar dispersal 251 patterns. Their mean traveling direction corresponded roughly to the direction of Masirah Island (Oman) which hosts a major loggerhead rookery. N1-N5 traveled to the Omanese and Yemeni coasts more than $3500 \mathrm{~km}$ away from the release point. N6-N9 headed to the south coast of Somalia and followed the coast northwards. N9 remained in a narrow strip some 30 $\mathrm{km}$ long off the Somali coast for more than 3 months. The PTTs of N6-N8 stopped transmitting while they were heading north.

The four southern turtles (S1-S4) traveled more than $1500 \mathrm{~km}$ away from the release point. S1-S3 travelled south-west whilst S4 first went southward and later eastwards in the $\mathrm{X} 1$ and $\mathrm{X} 2$ remained in the open ocean. They followed atypical westward pathways moving toward Madagascar either straight (X1) or with loops (X2). X3 followed a northerly route and remained in the vicinity of St-Brandon islands (670 km from Reunion Island) for more than 3 months. Similarly, X4 and X5 headed north but they remained in the oceanic zone. Their 
movement patterns at the end of the transmission, around 1,100 km away from the release site, were similar to the patterns displayed by the turtles of the northern group.

\section{Movement behavior types}

Behavioral modes - oceanic transit" (OT), coastal transit (CT), oceanic residency (OR), or coastal residency (CR) - along each current corrected track are shown in Online Resource 2.

Overall, turtles spent most of their time in transit, and more specifically in ocean transit (OT: $51.5 \pm 36.6 \%$, CT: $8.5 \pm 19.0 \%$, OR: $1.8 \pm 35.0 \%, \mathrm{CR}: 0.5 \pm 12.3 \%, \mathrm{n}=18$ ). The PTTs of two turtles, X1 and X2, stopped transmitting while they were considered in OT. X3 spent 100 days in CR off St-Brandon islands and remained there until transmission was interrupted. Turtles of the southern group (S1-S4) exhibited almost exclusively OT or OR. These individuals did not travel along coastal areas except near the islands of Reunion and Mauritius shortly after release. None of them exhibited coastal residency. S2 and S3 noticeably exhibited long OR periods (113 days $(72.7 \%)$ and 288 days $(73.3 \%)$ respectively). Both turtles traveled along large circles (150-300 km of radius) either clockwise or anti-clockwise. S4 exhibited a slightly different movement behavior than other southern turtles as it spent most its time (53.2\%) in OT. Individuals of the northern group traveled longer distances either in the open ocean or in the coastal areas of Somalia. N9 remained for 75 days in CR along a very narrow area of the Somalian coast. Once reaching the Omani and Yemeni waters, N1, N2 and N5 alternated long OR with short CR phases. Other individuals did not reach latitudes north of $10^{\circ} \mathrm{N}$ during their tracking periods.

\section{Diving behavior}

A total of 23,362 dive durations (from 14 turtles) and 18,688 dives depths (from 10 turtles) 
shallower than $30 \mathrm{~m}$ and that $98.5 \pm 1.2 \%(\mathrm{n}=10)$ of dives were shallower than $100 \mathrm{~m}$.

292 Another peak with larger dive frequencies appears around $55 \mathrm{~m}$. Dive duration data demonstrated that $57.1 \pm 12.9 \%(\mathrm{n}=14)$ dives were shorter than 2 minutes and $88.9 \pm 6.6 \%$ $(n=14)$ shorter than 30 minutes where a second peak appears in the number of dives.

Mean frequencies of dives assigned to each dive type Dss, Dsl, Ddl and Dl were respectively $80.0 \pm 10.8 \%(n=14), 4.6 \pm 3.8 \%(n=10), 13.1 \pm 7.8 \%(n=10)$ and $9.9 \pm 15.8 \%(n=4 ;$ Fig. $1)$.

There was a clear daily dichotomy in turtles' diving behavior (Fig. 3 and Fig. 4), with diurnal dives being significantly more numerous (Wilcoxon signed-rank test, $\mathrm{T}=55, \mathrm{P}=$ 0.002, $\mathrm{n}=10$ Fig. 3a) and shorter (Wilcoxon signed-rank test, $\mathrm{T}=1, \mathrm{P}=0.002, \mathrm{n}=10$, Fig. 3e, Table 3) than nocturnal dives. In addition, maximum dive depth was also significantly deeper at night (Wilcoxon signed-rank test, $\mathrm{T}=2, \mathrm{P}=0.006, \mathrm{n}=10$, Fig. 3c, Table 3). During daytime, turtles spent significantly more time just below the surface $(53.5 \pm 19.1 \%$ in $0-10 \mathrm{~m}$, $\mathrm{n}=10$, Table 3$)$ than at night $(20.7 \pm 11.4 \%$ in $0-10 \mathrm{~m}, \mathrm{n}=10$, Table 3 , Wilcoxon signed-rank test, $\mathrm{T}=55, \mathrm{P}=0.002)$. At night they spent half their time between $0-30 \mathrm{~m}(51.4 \pm 22.2 \%$ in 0-30 $\mathrm{m}, \mathrm{n}=10$ ) with a relatively homogenous distribution in the water column (Online Resource 1-Fig. 2). Time-at-depth for deepest layers (> $40 \mathrm{~m}$ ) did not differ between day (4.3 $\pm 5.7 \%, \mathrm{n}=10$, Table 3$)$ and night $(5.2 \pm 5.7 \%, \mathrm{n}=10$, Online Resource 1-Fig. 2, Table 3, Wilcoxon signed-rank test, $\mathrm{T}=36, \mathrm{P}=0.43$ ). These differences in diving behavior were confirmed by single dive parameters: short and shallow dives (Dss) were significantly more frequent during day hours $(86.4 \pm 12.8 \%, \mathrm{n}=14$, Table 3$)$ than during night hours $(73.0 \pm$ 8.9\%, $\mathrm{n}=14$, Table 3, Fig. 4, Wilcoxon signed-rank test, $\mathrm{T}=104, \mathrm{P}<0.001$ ). 


\section{Relation between diving and movement behavior}

315 Time spent just below the surface $(0-10 \mathrm{~m})$ was not clearly related to movement phases (OR, $316 \mathrm{CR}, \mathrm{CT}, \mathrm{OT})$. A difference in the usage of the water column located between $10 \mathrm{~m}$ and $20 \mathrm{~m}$

was observed, both during oceanic and coastal phases (Online Resource 1-Fig. 3). Turtles spent more time in this layer while they were in resident phases $(24.9 \pm 2.5 \%, \mathrm{n}=6$, Table 3$)$ than during transit periods $(8.8 \pm 6.4 \%, \mathrm{n}=6$, Table 3 , Mann-Whitney $\mathrm{U}$ test, $\mathrm{U}=13, \mathrm{P}=$ 0.036). The proportion of short and shallow dives (Dss) was slightly but not significantly more important during transit phases $(85.5 \pm 9.5 \%, \mathrm{n}=14$, Table 3$)$ than during residency phases $(74.5 \pm 5.4 \%, \mathrm{n}=7$, Table 3, Mann-Whitney $\mathrm{U}$ test, $\mathrm{U}=13, \mathrm{P}=0.055)$.

Slight differences were also observed in the usage of the deepest layers both during the open ocean and coastal phases (Online Resource 1-Fig. 3). The maximum dive depth of turtles during transit phases $(121.2 \pm 25.0 \mathrm{~m}, \mathrm{n}=9)$ was deeper than during resident phases $(100.0 \pm 50.0 \mathrm{~m}, \mathrm{n}=9$; Table 3, Mann-Whitney U test, $\mathrm{U}=56, \mathrm{P}=0.039)$. Nevertheless, the usage of the deepest layers (> $40 \mathrm{~m}$ ) were not significantly different whether animals were resident $(4.1 \pm 5.7 \%, \mathrm{n}=7$, Table 3$)$ or whether they were in transit $(6.5 \pm 5.1 \%, \mathrm{n}=14$, Table 3, Mann-Whitney $\mathrm{U}$ test, $\mathrm{U}=60, \mathrm{P}=0.44)$.

\section{Oceanic covariates}

The distributions of SST, NPP and TKE are illustrated in Fig. 5 and oceanic environment values are summarized in Table 4 (An illustration of the oceanic covariates for each individual track is provided in Online Resource 3). Most (95\%) of the turtles locations were associated with SSTs ranging from $17.12^{\circ} \mathrm{C}$ to $30.05^{\circ} \mathrm{C}$. S4 experienced the coldest SST $\left(11.5^{\circ} \mathrm{C}\right.$ by $\left.32.2^{\circ} \mathrm{S}\right)$ and $\mathrm{N} 6$ was exposed to the highest $\mathrm{SST}\left(31.9^{\circ} \mathrm{C}\right.$ by $\left.11.8^{\circ} \mathrm{S}\right)$. Turtles of the different groups were exposed to various levels of SST (Kruskal-Wallis test, $\mathrm{H}_{2}=9.30, \mathrm{P}=0.009$ ). 
exposed to colder SST $\left(19.4 \pm 0.72^{\circ} \mathrm{C}, \mathrm{n}=3\right)$ than individuals in the northern group $(27.7 \pm$ $0.61^{\circ} \mathrm{C}, \mathrm{n}=6$, Fig. 6a, Mann-Whitney $\mathrm{U}$ test, $\left.\mathrm{U}=36, \mathrm{P}=0.028\right)$. The other turtles were exposed to high SST of the same order of magnitude as northern turtles $\left(27.8 \pm 0.03^{\circ} \mathrm{C}, \mathrm{n}=2\right.$, Fig. 6a, Mann-Whitney $\mathrm{U}$ test, $\mathrm{U}=16, \mathrm{P}=0.44)$.

NPP levels were extremely variable along tracks, with $95 \%$ of values ranging from 125.0 $\mathrm{mg} \mathrm{C} \mathrm{m}^{-2}$ day $^{-1}$ to $1141.6 \mathrm{mg} \mathrm{C} \mathrm{m}^{-2} \mathrm{day}^{-1}$. The highest levels of NPP were observed along the coast of the Arabian Peninsula, with the highest level of NPP being recorded for N5 at $7801.1 \mathrm{mg} \mathrm{C} \mathrm{m}{ }^{-2}$ day $^{-1}$ near the south-east coast of Oman. During residency phases, individuals were exposed to varying levels of productivity, depending on their groups (Fig. 6a; Kruskal-Wallis test, $\left.\mathrm{H}_{2}=8.07, \mathrm{P}=0.017\right)$. Individuals of the undetermined group $(231.1 \pm$ $51.7 \mathrm{mg} \mathrm{C} \mathrm{m}^{-2} \mathrm{day}^{-1}, \mathrm{n}=2$, for undetermined group) were exposed to significantly lower NPP levels than individuals from the northern group $\left(424.7 \pm 345.3 \mathrm{mg} \mathrm{C} \mathrm{m}^{-2} \mathrm{day}^{-1}, \mathrm{n}=5\right.$, MannWhitney $\mathrm{U}$ test, $\mathrm{U}=5, \mathrm{P}=0.019)$ or the southern group $\left(396.9 \pm 146.7 \mathrm{mg} \mathrm{C} \mathrm{m}^{-2} \mathrm{day}^{-1}, \mathrm{n}=3\right.$, Mann-Whitney $\mathrm{U}$ test, $\mathrm{U}=1, \mathrm{P}=0.016)$.

OR phases occurred most frequently, but not exclusively, either below $30^{\circ} \mathrm{S}$ or above $10^{\circ}$ N. Several individuals then described circular movements (N1, N2, N5, N6, S2 and S3; see respective figures in Online Resource 2). These OR phases were related to oceanic mesoscale structures (Online Resource 1-Fig. 4), as supported by higher TKE values observed along the tracks during OR phases $\left(505.5 \pm 451 \mathrm{~cm}^{2} \mathrm{~s}^{-2}, \mathrm{n}=10\right)$ in comparison with OT phases $\left(449.0 \pm 202.5 \mathrm{~cm}^{2} \mathrm{~s}^{-2}, \mathrm{n}=18\right.$, Fig. $6 \mathrm{~b}$, Mann-Whitney $\mathrm{U}$ test, $\left.\mathrm{U}=1, \mathrm{P}=0.61\right)$. They were also exposed to higher levels of NPP during OR phases $\left(405.2 \pm 300 \mathrm{mg} \mathrm{C} \mathrm{m}^{-2}\right.$ day $^{-1}, \mathrm{n}=$ 10) than during OT phases $\left(262.0 \pm 80.6 \mathrm{mg} \mathrm{C} \mathrm{m}^{-2}\right.$ day $^{-1}, \mathrm{n}=18$, Mann-Whitney $\mathrm{U}$ test, $\mathrm{U}=$ $39, \mathrm{P}=0.014)$. 


\section{DISCUSSION}

All living organisms have to move at some point of their life history either by passive or active mechanisms (Holyoak et al. 2008). In a constantly changing and heterogeneous environment, animals interact with the physical environment, the resources and the habitats through their movement (Tilman and Kareiva 1997). Movement is therefore a key to the ecological dynamics of numerous species (Kendall and Fox 1998; Nathan et al. 2008). Sea turtles juvenile stage illustrates its importance. As our knowledge on juvenile loggerhead spatial ecology improves, there is growing evidence that the spatial fate of individuals during the early stages may have substantial effects on growth rates, life-stages duration and age at sexual maturity (Bjorndal et al. 2013). The results of the satellite tracking of eighteen juvenile loggerheads in the Indian Ocean provides new insight on the spatial ecology of the species in the region, but also first evidence of trans-equatorial movements with high latitudinal range.

\section{Regional dispersal}

One half $(50 \%)$ of the late juvenile loggerhead sea turtles tracked in this study went north towards one of the world's largest rookeries for the species (Fig. 2). Another important component $(22 \%)$ went south-west towards smaller rookeries (Fig. 2). The average size of first-time nesters is $84 \mathrm{~cm}$ in South Africa (Nel et al. 2013) and $91 \mathrm{~cm}$ in Oman (Ross and Barwani 1995) whilst the size of sexual maturity for this species is usually considered to be around $80 \mathrm{~cm}$ to $90 \mathrm{~cm}$ (Avens and Snover 2013). With an average curved carapace length of $68 \mathrm{~cm}$, the individuals we tracked were likely to be close to sexual maturity, but not mature, and therefore to be heading towards their natal site, as sea turtles tend to exhibit philopatry. This suggests that late juvenile loggerheads frequenting the Reunion Island and East Madagascar waters (location of capture, Online Resource 1-Fig. 1) may originate mainly from northerly rookeries, and also, from southerly ones. This suggests a trans-equatorial 
development cycle for the individuals originating from the northern rookeries. Population genetics could be used to confirm this hypothesis as genetics have been used to characterize the origin of individuals at large distance from their natal site (Monzon-Arguello et al. 2012; Monzón-Argüello et al. 2010).

The distances travelled by the individuals were substantial as is generally the case for juvenile sea turtles (Hays and Scott 2013). Nevertheless, while in the other oceans the loggerhead development occurs typically over broad spatial scales (e.g. more than $10,000 \mathrm{~km}$ in the Pacific Ocean; Bowen et al. 1995; Boyle et al. 2009), it is normally confined to a single hemisphere (see exception in Bowen et al. 1995). The trans-equatorial development cycle in the Indian Ocean appears therefore atypical.

The spatio-temporal pathways followed by juvenile loggerheads to reach the southwest Indian Ocean are still to be determined. Ocean currents are known to play a crucial role in the spatial fate of juveniles sea turtles (Musick and Limpus 1997). Noticeably, in both the Atlantic and Pacific Oceans, large oceanic gyres are persistent and predominantly constrained in a single hemisphere. In the Indian Ocean, the unique characteristics of the monsoon phenomenon make hydrodynamics particularly complex: no annual, persistent, and ocean scale gyre exists as cyclonic and anti-cyclonic complex gyres alternate during winter and summer monsoon periods (Schott and McCreary 2001; Schott et al. 2009). The pathway followed by hatchlings and early juvenile loggerheads from the Arabian Sea to the ocean waters around Reunion and Madagascar is likely to be more complex than in the other oceans. Following the general scheme of Indian Ocean circulation described in Schott et al. (2009), we hypothesize that hatchlings from Oman may drift eastward with the SouthEquatorial Counter Current (SECC), possibly up to the eastern part of the Indian Ocean Basin. They may then join the permanent South-Equatorial Current (SEC) and drift westward towards the Mascarene archipelago. In the absence of strong supporting evidence, this 
hypothesis should however be treated with caution. Furthermore, considering the seasonal

414 characteristics and the complexity of the oceanic circulation in the Indian Ocean, we can

415 surmise that more variability in the development cycle and hatching dispersal of loggerheads,

416 may exist in Indian Ocean hatchling dispersal than for loggerhead populations in other

417 oceans. Drift modeling should provide valuable information regarding these drift patterns as

418 they are now extensively used (Hays et al. 2010; Putman et al. 2012; Scott et al. 2012;

419 Shillinger et al. 2012; Gaspar et al. 2012).

\section{Space utilization}

In others oceans, various loggerhead foraging behaviors have been observed during the development stages. Juveniles generally settle in neritic habitats but may occasionally remain, or re-enter, the open ocean environment (McClellan and Read 2007; Mansfield et al. 2009; McClellan et al. 2010). Both behaviors were observed in our study. Demographic implications of this alternative foraging strategy are discussed in Peckham et al. (2011). For example, while open ocean individuals may be exposed to slower growth rates due to lower prey availability, this disadvantage may be negated through having a lower predation risk than a purely coastal strategy.

It is noteworthy that three individuals remained in the vicinity of the coast of Yemen and Oman and their movements were similar to the post-nesting movements of nesting adults from Oman that forage in the same area (Rees et al. 2010). It is also worth noting that no neritic settlement was observed in the southern group where all turtles remain in the open ocean. In contrast, to the northern group, movements of late juveniles of the southern group differed from the movements of adults nesting in South Africa that are known to forage in the neritic zone along the coast of South Africa (even along the Atlantic side, Hughes 1974), 
Madagascar (Rakotonirina Berthin, IHSM, Pers. Com.). Nevertheless, circular movements around the oceanic eddies of the Agulhas Rings have been observed in adult leatherback sea turtles (Luschi et al. 2006; Doyle et al. 2008; Galli et al. 2012) demonstrating the interest of the region for sea turtles during the oceanic phases.

Individual turtles did not generally spend much time around the island where they were captured and tended to leave the area shortly after release. The region must be regarded as transit zone or a migratory corridor for late juveniles heading towards more productive areas in the South or in the North and simply passing through Reunion Island waters where they are accidentally captured. More data are required to confirm this hypothesis.

\section{Diving behavior}

The diurnal vs. nocturnal dichotomy in diving behavior, with more dives occurring during the day and longer dives at night, has already been observed (Renaud and Carpenter 1994; Houghton et al. 2002; Godley et al. 2003; Howell et al. 2010). Howell et al. (2010) also found that late juvenile loggerheads spend more time in the $0-15 \mathrm{~m}$ depth layer during the night than during the day and that they make more dives deeper than $15 \mathrm{~m}$ during the day. With slightly different bins (0-10m), we made similar observations. The dichotomy observed in the diving behavior may result from nocturnal resting dives and diurnal subsurface active dives (Godley et al. 2003).

During residency phases, turtles made more use of the 10-20 m layer than during transit periods, but made less use of the deeper layers $(>40 \mathrm{~m})$. This was observed for both coastal and open ocean phases. For coastal phases, this may be explained by the shallower waters allowing turtles to reach ocean bottom. During open ocean phases, prey availability at shallower depth may occur under specific conditions, and could explain the observed behavior of loggerheads. The association of oceanic residency phases with oceanic frontal zones, as 
commonly observed in a variety of taxonomic groups such as birds and large pelagic fishes (Fonteneau et al. (2008); Tew Kai et al. (2009); Tew Kai and Marsac (2010); Online Resource 1-Fig. 4) supports this hypothesis but needs to be investigated more deeply in the future. Observations of occasional, and exceptionally deep dive events ( $>80 \mathrm{~m}$ ) occurring mostly during transit phases, are difficult to interpret. Individuals may be inspecting the water column looking for prey as it has been suggested for the leatherback sea turtle (Houghton et al. 2008). They may also attempt to reduce silhouetting against the surface and exposure to predators, or eventually to reach the sea bottom to check for the proximity of seamounts or coastal areas as these two behaviors have been suggested for green turtles (Hays et al. 2001; Rice and Balazs 2008).

\section{Oceanic environment}

Environmental conditions for northern and southern groups were drastically different. According to world Ocean partitioning of Longhurst (1998), the Indian Ocean consists mainly of two large biogeochemical provinces: the Indian Monsoon Gyre Province (MONS) in the north and the Indian South Subtropical Gyre Province (ISSG) in the south. MONS is bordered by the Northwest Arabian Sea Upwelling Longhurst province (ARAB). This province, included in the Arabian Large Marine Ecosystem, is considered a highly productive ecosystem (Heileman et al. 2009) with intense large scale seasonal coastal upwelling and a productive phytoplankton bloom system (Lévy et al. 2007). The southern region also exhibits extensive coastal upwelling leading to the productive Agulhas Current large marine ecosystem (Heileman et al. 2009). In addition, interactions, between meso-scale structures that take place in the Mozambique Channel, generate strong frontal mixing zones favorable to the production and aggregation of organic matter (Tew Kai and Marsac 2009). As a consequence, individuals 
of the northern and southern groups frequented more productive waters than the individuals that remained close to the release site.

There was a major difference in the sea surface temperature to which turtles were exposed, with clearly higher temperatures for the northern group $\left(27.6^{\circ} \mathrm{C}\right)$ than the southern group $\left(20.4^{\circ}\right.$ C; Fig. 6). Nevertheless turtles from the southern group remained in relatively warm waters for loggerhead sea turtles. For example, in the Pacific Ocean, loggerheads frequent waters with temperatures between $14.5^{\circ} \mathrm{C}$ and $20^{\circ} \mathrm{C}$ (Kobayashi et al. 2008), and Coles et al. (2000) have suggested a lower thermal boundary of $13.3^{\circ} \mathrm{C}$.. Such environmental difference should potentially lead to contrasted life histories. For example, growth rates have been shown to be strongly decreasing with lower sea surface temperatures and may therefore lead to lower growth rates for the turtles exploiting the southern habitats (Hughes 1974).

\section{Conservation implications}

Pelagic longlines, through incidental bycatch, has a high impact on loggerhead populations. (Lewison et al. 2004; Peckham et al. 2007). In the Western Indian Ocean, longline bycatch was identified as one of the possible reason explaining the slow recovery of the South African population (Petersen et al. 2009). The loggerheads tracked in this study were caught accidentally by the small French longline fishing fleet operating around Reunion Island and the East-Madagascar EEZs (Evano and Bourjea 2012). The number of individuals accidentally caught by this fishery is assumed to be low (Miossec and Bourjea 2003). The fact that most of the longline gears are set deeper than $40 \mathrm{~m}$ around Reunion Island, could explain the relatively low incidence of turtle bycatch occurring within the area

Considering the large size of loggerhead populations in the northern Indian Ocean from which a majority of individuals seems to originate, any negative impact of the Reunion Island longline fleet is likely to be moderate. Encouraging collaboration between fishermen and the 
512 local sea turtle care centre (Ciccione and Bourjea 2010) should contribute to a reduction of 513 this impact. Existing mitigation measures, such as the use of adapted circle hooks (Read 514 2007), the reduction of gear soak time, the avoidance of hotspots and the setting of gear below 515 turtle-abundant depths (Polovina et al. 2003; Gilman et al. 2006; Howell et al. 2010), are also 516 to be encouraged locally.

\section{Summary}

In the present study, the first evidence of ocean scale trans-equatorial movements was demonstrated for juvenile loggerhead turtles. This has value for conservation, as threats are identified and protection measures can be developed. It was also shown that southern and northern open ocean juvenile loggerhead turtles target waters with high levels of productivity, although the southern group was exposed to lower sea temperatures. The consequent influence on growth rates and on survival rates might have high impact on population dynamics, viability and recovery. While this is a modest advance in the knowledge of juvenile loggerhead movement ecology, major questions remain. The routes followed by these individuals from their original rookeries to Reunion island waters are yet to be determined and whether the trans-equatorial development cycle suggested by the results for the northern rookeries is prevalent or if it's only an artifact of the small number of loggerhead turtles tracked, remains to be confirmed. Regional genetic and stable isotopes studies, as well as drift simulations could help to answer key issues regarding the survival of loggerhead turtles from hatchling to adult.

\section{ACKNOWLEDGMENTS}

The authors are grateful to the organizations that contributed to funding the study: DEAL La 
537 Réunion. Mayeul Dalleau personally thanks Région Réunion for funding his PhD studentship.

538 The authors also wish to thank all the people and organizations that made this study possible,

539 especially those boat captains and crew members of Réunion Island longline vessels boats that

540 collaborated with the program; Francis Schneider and his veterinary team for surgical

541 operations and medical care, the Kélonia team for medical care and awareness programs, the

542 school children and teachers for sponsorships, Dr. Georges Hughes for correcting the English

543 of the current article. The study was conducted under authorization $\mathrm{N}^{\circ} 09-1405 / \mathrm{SG} / \mathrm{DRCTCV}$

544 issued by the Reunion Island prefecture on 2009-05-11. At last, we wish to thank the

545 reviewers that contributed improving this paper and the editor for his useful comments. 
Arendt MD, Segars AL, Byrd JI, Boynton J, Whitaker JD, Parker L, Owens DW, Blanvillain G, Quattro JM, Roberts MA (2012) Seasonal distribution patterns of juvenile loggerhead sea turtles (Caretta caretta) following capture from a shipping channel in the Northwest Atlantic Ocean. Mar Biol 159 (1):127-139. doi:10.1007/s00227-011-1829-x

Avens L, Snover M (2013) Age and Age Estimation in Sea Turtles. In: The Biology of Sea Turtles, Volume III. Marine Biology. CRC Press, pp 97-134. doi:10.1201/b13895-6

Baldwin RM, Hughes GR, Prince RIT (2003) Loggerhead turtles in the Indian Ocean. In: Loggerhead sea turtles. Smithsonian Books, Washington, DC, pp 218-232

Barraquand F, Benhamou S (2008) Animal movements in heterogeneous landscapes: identifying profitable places and homogeneous movement bouts. Ecology 89 (12):3336-3348. doi:10.1890/08-0162.1

Behrenfeld MJ, Falkowski PG (1997) Photosynthetic rates derived from satellite-based chlorophyll concentration, vol 42. vol 1. American Society of Limnology and Oceanography, Waco, Texas, USA

Bjorndal K, Schroeder B, Foley A, Witherington B, Bresette M, Clark D, Herren R, Arendt M, Schmid J, Meylan A, Meylan P, Provancha J, Hart K, Lamont M, Carthy R, Bolten A (2013) Temporal, spatial, and body size effects on growth rates of loggerhead sea turtles (Caretta caretta) in the Northwest Atlantic. Mar Biol:1-11. doi:10.1007/s00227-013-2264-y

Bjorndal KA, Bolten AB, Martins HR (2000) Somatic growth model of juvenile loggerhead sea turtles Caretta caretta: duration of pelagic stage. Mar Ecol-Prog Ser 202:265-272. doi: $10.3354 /$ meps 202265

Bolten AB (2003) Variation in Sea Turtle Life History Patterns: Neritic vs. Oceanic Developmental Stages. In: Lutz PL, Musick A, Wyneken J (eds) The biology of sea turtles, vol 2. vol Marine science series. CRC Press, Boca Raton, Florida, pp 243-258

Bowen BW, Abreu-Grobois FA, Balazs GH, Kamezaki N, Limpus CJ, Ferl RJ (1995) Trans-Pacific migrations of the loggerhead turtle (Caretta caretta) demonstrated with mitochondrial DNA markers. Proceedings of the National Academy of Sciences 92 (9):3731-3734. doi:10.1073/pnas.92.9.3731

Bowen BW, Karl SA (2007) Population genetics and phylogeography of sea turtles. Molecular Ecology 16 (23):4886-4907. doi:10.1111/j.1365-294X.2007.03542.x

Boyle MC, FitzSimmons NN, Limpus CJ, Kelez S, Velez-Zuazo X, Waycott M (2009) Evidence for transoceanic migrations by loggerhead sea turtles in the southern Pacific Ocean. Proceedings of the Royal Society B-Biological Sciences 276 (1664):1993-1999. doi:10.1098/rspb.2008.1931

Breed GA, Jonsen ID, Myers RA, Bowen WD, Leonard ML (2009) Sex-specific, seasonal foraging tactics of adult grey seals (Halichoerus grypus) revealed by state-space analysis. Ecology 90 (11):3209-3221. doi:10.1890/07-1483.1

Carr AF (1952) Handbook of turtles : the turtles of the United States, Canada, and Baja California

Carr AF (1986) The sea turtle: so excellent a fishe. University of Texas Press,

Ciccione S, Bourjea J (2010) Discovering behaviour of open sea stages of sea turtles: working flipper on hand with fishermen in Réunion. Indian Ocean turtle newsletter (11):p50-52

Coles W, Musick JA, Price AH (2000) Satellite Sea Surface Temperature Analysis and Correlation with Sea Turtle Distribution off North Carolina. Copeia 2000 (2):551-554. doi:10.1643/00458511(2000)000[0551:ssstaa]2.0.co;2

Doyle TK, Houghton JD, O’Súilleabháin PF, Hobson VJ, Marnell F, Davenport J, Hays GC (2008) Leatherback turtles satellite-tagged in European waters. Endangered Species Research 4 (12):23-31. doi:10.3354/esr00076

Evano H, Bourjea J Atlas de la pêche palangrière réunionnaise de l'océan Indien. In, 2012. p 245pp. doi:RST -DOI/2012-11 
Fonteneau A, Lucas V, Tewkai E, Delgado A, Demarcq H (2008) Mesoscale exploitation of a major tuna concentration in the Indian Ocean. Aquatic Living Resources 21 (2):109-121. doi:10.1051/alr:2008028

Galli S, Gaspar P, Fossette S, Calmettes B, Hays GC, Lutjeharms JRE, Luschi P (2012) Orientation of migrating leatherback turtles in relation to ocean currents. Animal Behaviour 84 (6):14911500. doi:http://dx.doi.org/10.1016/j.anbehav.2012.09.022

Gaspar P, Benson SR, Dutton PH, Reveillere A, Jacob G, Meetoo C, Dehecq A, Fossette S (2012) Oceanic dispersal of juvenile leatherback turtles: going beyond passive drift modeling. Mar Ecol-Prog Ser 457:265-284. doi:10.3354/meps09689

Gilman E, Zollett E, Beverly S, Nakano H, Davis K, Shiode D, Dalzell P, Kinan I (2006) Reducing sea turtle by-catch in pelagic longline fisheries. Fish and Fisheries 7 (1):2-23. doi:10.1111/j.14672979.2006.00196.x

Girard C, Sudre J, Benhamou S, Roos D, Luschi P (2006) Homing in green turtles Chelonia mydas: oceanic currents act as a constraint rather than as an information source. Marine Ecology Progress Series 322:281-289. doi:10.3354/meps322281

Godley BJ, Broderick AC, Glen F, Hays GC (2003) Post-nesting movements and submergence patterns of loggerhead marine turtles in the Mediterranean assessed by satellite tracking. J Exp Mar Biol Ecol 287 (1):119-134. doi:10.1016/s0022-0981(02)00547-6

Halpin PN, Read AJ, Fujioka E, Best BD, Donnelly B, Hazen LJ, Kot C, Urian K, LaBrecque E, Dimatteo A, Cleary J, Good C, Crowder LB, Hyrenbach KD (2009) OBIS-SEAMAP: The World Data Center for Marine Mammal, Sea Bird, and Sea Turtle Distributions. Oceanography 22 (2):104-115

Hawkes LA, Broderick AC, Coyne MS, Godfrey MH, Lopez-Jurado L-F, Lopez-Suarez P, Merino SE, Varo-Cruz N, Godley BJ (2006) Phenotypically Linked Dichotomy in Sea Turtle Foraging Requires Multiple Conservation Approaches. Current biology : CB 16 (10):990-995

Hays GC, Akesson S, Broderick AC, Glen F, Godley BJ, Luschi P, Martin C, Metcalfe JD, Papi F (2001) The diving behaviour of green turtles undertaking oceanic migration to and from Ascension Island: dive durations, dive profiles and depth distribution. J Exp Biol 204 (23):4093-4098

Hays GC, Fossette S, Katselidis KA, Mariani P, Schofield G (2010) Ontogenetic development of migration: Lagrangian drift trajectories suggest a new paradigm for sea turtles. Journal of the Royal Society Interface 7 (50):1319-1327. doi:10.1098/rsif.2010.0009

Hays GC, Scott R (2013) Global patterns for upper ceilings on migration distance in sea turtles and comparisons with fish, birds and mammals. Funct Ecol 27 (3):748-756. doi:10.1111/13652435.12073

Heileman S, Eghtesadi-Araghi P, Mistafa N (2009) Arabian Sea : LME. The Unep large marine ecosystems report, a perspective on changing conditions in MLEs of the world's regional seas, vol UNEP Regional Seas Report and Studies. Nairobi, Kenya

Hoenner X, Whiting SD, Hindell MA, McMahon CR (2012) Enhancing the Use of Argos Satellite Data for Home Range and Long Distance Migration Studies of Marine Animals. Plos One 7 (7). doi:10.1371/journal.pone.0040713

Holyoak M, Casagrandi R, Nathan R, Revilla E, Spiegel O (2008) Trends and missing parts in the study of movement ecology. Proceedings of the National Academy of Sciences 105 (49):19060-19065

Houghton JDR, Broderick AC, Godley BJ, Metcalfe JD, Hays GC (2002) Diving behaviour during the internesting interval for loggerhead turtles Caretta caretta nesting in Cyprus. Mar Ecol-Prog Ser 227:63-70

Houghton JDR, Doyle TK, Davenport J, Wilson RP, Hays GC (2008) The role of infrequent and extraordinary deep dives in leatherback turtles (Dermochelys coriacea). Journal of Experimental Biology 211 (16):2566-2575. doi:10.1242/jeb.020065

Howell E, Dutton P, Polovina J, Bailey H, Parker D, Balazs G (2010) Oceanographic influences on the dive behavior of juvenile loggerhead turtles (Caretta caretta) in the North Pacific Ocean. Mar Biol 157 (5):1011-1026. doi:10.1007/s00227-009-1381-0

Hughes GR (1973) The sea turtles of south east Africa. . Doctoral thesis, University of Natal, Durban 
Hughes GR (1974) The sea turtles of South-East Africa II. The biology of the Tongaland loggerhead turtle Caretta caretta L. with comments on the leatherback turtle Dermochelys coriacea L. and the green turtle Chelonia mydas L. in the study region. Investigational Report.

Hughes GR (2010) Loggerheads and leatherbacks in the Western Indian Ocean. Indian Ocean Turtle Newsletter 11:24-31

Hughes GR (2012) Between the tides. Jacana Publishers, Cape Town

IUCN (2012) The IUCN Red List of Threatened Species. http://www.iucnredlist.org/. Accessed 01 June 2013

Kendall BE, Fox GA (1998) Spatial Structure, Environmental Heterogeneity, and Population Dynamics: Analysis of the Coupled Logistic Map. Theoretical Population Biology 54 (1):1137. doi:http://dx.doi.org/10.1006/tpbi.1998.1365

Kobayashi DR, Polovina JJ, Parker DM, Kamezaki N, Cheng IJ, Uchida I, Dutton PH, Balazs GH (2008) Pelagic habitat characterization of loggerhead sea turtles, Caretta caretta, in the North Pacific Ocean (1997-2006): Insights from satellite tag tracking and remotely sensed data. J Exp Mar Biol Ecol 356 (1-2):96-114

Lavielle M (2005) Using penalized contrasts for the change-point problem. Signal Processing 85 (8):1501-1510. doi:10.1016/j.sigpro.2005.01.012

Lévy M, Shankar D, André JM, Shenoi SSC, Durand F, de Boyer Montégut C (2007) Basin-wide seasonal evolution of the Indian Ocean's phytoplankton blooms. Journal of Geophysical Research: Oceans 112 (C12):C12014. doi:10.1029/2007jc004090

Lewison RL, Freeman SA, Crowder LB (2004) Quantifying the effects of fisheries on threatened species: the impact of pelagic longlines on loggerhead and leatherback sea turtles. Ecology Letters 7 (3):221-231. doi:10.1111/j.1461-0248.2004.00573.x

Longhurst AR (1998) Ecological Geography of the Sea. Academic Press, San Diego

Luschi P, Lutjeharm JRE, Lambardi R, Mencacci R, Hughes GR, Hays GC (2006) A review of migratory behaviour of sea turtles off Southeastern Africa. South African Journal of Science 102 (1-2):51-58

Mansfield K, Saba V, Keinath J, Musick J (2009) Satellite tracking reveals a dichotomy in migration strategies among juvenile loggerhead turtles in the Northwest Atlantic. Mar Biol 156 (12):2555-2570. doi:10.1007/s00227-009-1279-x

Martel B (2003) Les facteurs intervenant dans la selection des sites de ponte de la caouanne (Caretta caretta) sur les côtes malgaches, vol 79. vol 4. Société de biogéographie, Paris, France

McClellan CM, Braun-McNeill J, Avens L, Wallace BP, Read AJ (2010) Stable isotopes confirm a foraging dichotomy in juvenile loggerhead sea turtles. J Exp Mar Biol Ecol 387 (1-2):44-51. doi:10.1016/j.jembe.2010.02.020

McClellan CM, Read AJ (2007) Complexity and variation in loggerhead sea turtle life history. Biology Letters 3 (6):592-594. doi:10.1098/rsbl.2007.0355

Miossec D, Bourjea J (2003) Longline fishery evolution in La Réunion. Focus on the exploitation level of swordfish (Xiphias gladius). Paper presented at the 3rd Session of the IOTC Working Party on Billfish, Perth, Australia, 10-12 Nov

Monzon-Arguello C, Dell'Amico F, Moriniere P, Marco A, Lopez-Jurado LF, Hays GC, Scott R, Marsh R, Lee PLM (2012) Lost at sea: genetic, oceanographic and meteorological evidence for storm-forced dispersal. Journal of the Royal Society Interface 9 (73):1725-1732. doi:10.1098/rsif.2011.0788

Monzón-Argüello C, López-Jurado LF, Rico C, Marco A, López P, Hays GC, Lee PLM (2010) Evidence from genetic and Lagrangian drifter data for transatlantic transport of small juvenile green turtles. Journal of Biogeography 37 (9):1752-1766. doi:10.1111/j.13652699.2010.02326.x

Musick JA, Limpus CJ (1997) Habitat utilization and migration in juvenile sea turtles. In: Lutz PL, Musick JA (eds) The biology of sea turtles. vol Marine science series. CRC Press, Boca Raton, Florida, pp p137-163

Nathan R, Getz WM, Revilla E, Holyoak M, Kadmon R, Saltz D, Smouse PE (2008) A movement ecology paradigm for unifying organismal movement research. Proceedings of the National Academy of Sciences 105 (49):19052-19059. doi:10.1073/pnas.0800375105 
Nel R, Punt AE, Hughes GR (2013) Are Coastal Protected Areas Always Effective in Achieving Population Recovery for Nesting Sea Turtles? Plos One 8 (5):e63525. doi:10.1371/journal.pone.0063525

Peckham SH, Maldonado-Diaz D, Tremblay Y, Ochoa R, Polovina J, Balazs G, Dutton PH, Nichols WJ (2011) Demographic implications of alternative foraging strategies in juvenile loggerhead turtles Caretta caretta of the North Pacific Ocean. Mar Ecol-Prog Ser 425:269-280. doi:10.3354/meps08995

Peckham SH, Maldonado Diaz D, Walli A, Ruiz G, Crowder LB, Nichols WJ (2007) Small-scale fisheries bycatch jeopardizes endangered Pacific loggerhead turtles. Plos One 2 (10):e1041

Petersen SL, Honig MB, Ryan PG, Nel R, Underhill LG (2009) Turtle bycatch in the pelagic longline fishery off southern Africa. African Journal of Marine Science 31 (1):87-96. doi:10.2989/ajms.2009.31.1.8.779

Polovina JJ, Balazs GH, Howell EA, Parker DM, Seki MP, Dutton PH (2004) Forage and migration habitat of loggerhead (Caretta caretta) and olive ridley (Lepidochelys olivacea) sea turtles in the central North Pacific Ocean. Fish Oceanogr 13 (1):36-51

Polovina JJ, Howell E, Parker DM, Balazs GH (2003) Dive-depth distribution of loggerhead (Carretta carretta) and olive ridley (Lepidochelys olivacea) sea turtles in the central North Pacific: Might deep longline sets catch fewer turtles? Fishery Bulletin 101 (1):189-193

Putman N, Scott R, Verley P, Marsh R, Hays G (2012) Natal site and offshore swimming influence fitness and long-distance ocean transport in young sea turtles. Mar Biol 159 (10):2117-2126. doi:10.1007/s00227-012-1995-5

Rakotonirina BP (2011) Etude éthno-biologique sur tortues marines à Madagascar (Sud-Ouest de l'océan Indien). PhD Thesis, Université de Toliara, Toliara

Read AJ (2007) Do circle hooks reduce the mortality of sea turtles in pelagic longlines? A review of $\begin{array}{llll}\text { recent experiments. Biological Conservation } 135 & \text { (2):155-169. }\end{array}$ doi:10.1016/j.biocon.2006.10.030

Rees A, Al Saady S, Broderick A, Coyne M, Papathanasopoulou N, Godley B (2010) Behavioural polymorphism in one of the world's largest populations of loggerhead sea turtles Caretta caretta. Marine Ecology Progress Series 418:201-212. doi:10.3354/meps08767

Renaud ML, Carpenter JA (1994) Movements and submergence patterns of loggerhead turtles (Caretta caretta) in the Gulf-of-Mexico determined through satellite telemetry. Bulletin of Marine Science 55 (1):1-15

Revelles M, Isem-Fontanet J, Cardona L, Felix MS, Carreras C, Aguilar A (2007) Mesoscale eddies, surface circulation and the scale of habitat selection by immature loggerhead sea turtles. J Exp Mar Biol Ecol 347 (1-2):41-57. doi:10.1016/j.jembe.2007.03.013

Rice MR, Balazs GH (2008) Diving behavior of the Hawaiian green turtle (Chelonia mydas) during oceanic migrations. J Exp Mar Biol Ecol 356 (1-2):121-127

Ross JP (1998) Estimations of the nesting population size of loggerhead sea turtles, Caretta caretta, Masirah Island, Sultanate of Oman. NMFS-SEFSC,

Ross JP, Barwani MA (1995) Review of sea turtles in the Arabian area. In: Bjorndal KA (ed) Biology and conservation of sea turtles, revised edition. Smithsonian Institute Press, Washington, DC, pp 373-383

Savtchenko A, Ouzounov D, Ahmad S, Acker J, Leptoukh G, Koziana J, Nickless D (2004) Terra and Aqua MODIS products available from NASA GES DAAC. Advances in Space Research 34 (4):710-714. doi:10.1016/j.asr.2004.03.012

Schott FA, McCreary JP (2001) The monsoon circulation of the Indian Ocean. Progress in Oceanography 51 (1):1-123. doi:10.1016/s0079-6611(01)00083-0

Schott FA, Xie S-P, McCreary JP, Jr. (2009) Indian Ocean circulation and climate variability. Rev Geophys 47 (1):RG1002. doi:10.1029/2007rg000245

Scott R, Marsh R, Hays GC (2012) Life in the really slow lane: loggerhead sea turtles mature late relative to other reptiles. Funct Ecol 26 (1):227-235. doi:10.1111/j.1365-2435.2011.01915.x

Shillinger GL, Di Lorenzo E, Luo H, Bograd SJ, Hazen EL, Bailey H, Spotila JR (2012) On the dispersal of leatherback turtle hatchlings from Mesoamerican nesting beaches. Proceedings of the Royal Society B: Biological Sciences 279 (1737):2391-2395. doi:10.1098/rspb.2011.2348 
Sudre J, Maes C, Garçon V (2013) On the global estimates of geostrophic and Ekman surface currents. Limnology \& Oceanography: Fluids \& Environments 3:1-20. doi:10.1215/21573689-2071927

Tew Kai E, Marsac F (2009) Patterns of variability of sea surface chlorophyll in the Mozambique Channel: A quantitative approach. Journal of Marine Systems 77 (1-2):77-88. doi:10.1016/j.jmarsys.2008.11.007

Tew Kai E, Marsac F (2010) Influence of mesoscale eddies on spatial structuring of top predators' communities in the Mozambique Channel. Progress in Oceanography 86 (1-2):214-223. doi:10.1016/j.pocean.2010.04.010

Tew Kai E, Rossi V, Sudre J, Weimerskirch H, Lopez C, Hernandez-Garcia E, Marsac F, Garçon V (2009) Top marine predators track Lagrangian coherent structures. Proceedings of the National Academy of Sciences 106 (20):8245-8250. doi:10.1073/pnas.0811034106

Tilman DE, Kareiva PME (1997) Spatial Ecology: The Role of Space in Population Dynamics and Interspecific Interactions. Princeton University Press,

Wyneken J, Salmon M (1992) Frenzy and postfrenzy swimming activity in loggerhead, green, and leatherback hatchling sea-turtles. Copeia (2):478-484 


\section{FIGURES}

776 Fig. 1 Dive depth vs. dive duration for pooled single dives of 10 late

777

778 juvenile loggerhead sea turtles. Density plot clearly outline 2 modes (dark grey) defined here as Dss and Ddl, respectively representing short and shallow $(<30 \mathrm{~m},<800 \mathrm{sec})$ and long and deep $(>=30 \mathrm{~m}$, $>=800 \mathrm{sec}$ ) dives. Another number of dives, yet less numerous, was identified and defined as Dsl dives, long and shallow $(<30 \mathrm{~m}$, $>=800 \mathrm{sec}$ ). Only dives superior to $30 \mathrm{sec}$ and $2 \mathrm{~m}$ were considered for the purpose of this analysis.

Fig. 2 Satellite tracks of 18 late juvenile loggerhead individuals released after accidental captured by long-line fishing boats in the vicinity of Reunion Island. Individuals were classified in three groups: North (red), and South (Blue).

Fig. 3 Pooled distributions of integrated parameters of late juvenile loggerhead sea turtles over $24 \mathrm{~h}, 12 \mathrm{~h}$ daytime and $12 \mathrm{~h}$ night time: (a) Number of dives $(n=14)$, (b) underwater percentage ( $n=14)$, (c) maximum dive depth $(n=10)$, (d) maximum dive duration $(n=14),(e)$ mean dive duration $(n=14)$. Diurnal dives are more numerous and shorter than nocturnal dives. Maximum dive depth is also significantly deeper at night. 
795 Fig. 4 Percentage of Dss, Dsl and Ddl dives of 10 late juvenile loggerhead sea turtles according to day hour (GMT+4). Dss are subsurface and short dives $(<30 \mathrm{~m},<800 \mathrm{~s})$, Dsl are shallow and long dives $(<30 \mathrm{~m}$, $>=800 \mathrm{~s})$ and Ddl are deep and long dives ( $>=30 \mathrm{~m},>800 \mathrm{~s})$. Short and shallow dives are more frequent at day time while longer dives are more frequent during night time.

Fig. 5 Distributions of environmental variables along the 18 turtle's tracks: (a) Sea Surface Temperature $\left({ }^{\circ} \mathrm{C}\right)$, (b) net primary production (mgC m${ }^{-2}$ day $\left.^{-1}\right)$, (c) total kinetic energy $\left(\mathrm{cm}^{2} \mathrm{~s}^{-2}\right)$. Coldest SST appears at the most southern locations. NPP levels are higher at more extreme latitudinal locations in the South and in the North and are lower in the equatorial locations. TKE values are more homogeneously dispersed.

Fig. 6 (a) Comparison of Net Primary Production (NPP) and Sea Surface Temperature (SST) between late juvenile loggerhead individuals from the northern group $(n=11)$ and individuals from the southern group $(n=4)$. NPP reaches higher levels for turtle of the northern and southern group. Individual from the southern group are exposed to lower SSTs. (b) Comparison of NPP and Total Kinetic Energy (TKE) during oceanic transit phases (OT) and oceanic resident phases (OR). NPP levels are higher during resident phases. Higher TKE levels also occur during resident phases. 
818 Table 1 Demographic (CCL, body mass), distribution and migration parameters for 18 late juveniles loggerhead sea turtles satellitetagged after accidental capture from long-liners from Reunion Island, Indian Ocean (Online Resource 1-Fig. 1). Spatial group, distance from released point and bearing from released point are evaluated from last tracking location. Mean travel speed is calculated using tracks interpolated with 3 locations per day.

\begin{tabular}{|c|c|c|c|c|c|c|c|c|c|}
\hline $\begin{array}{l}\text { Turtle } \\
\text { ID }\end{array}$ & $\begin{array}{l}\text { Captivity } \\
\text { period } \\
\text { (days) }\end{array}$ & $\begin{array}{l}\mathrm{CCL} \\
(\mathrm{cm})\end{array}$ & $\begin{array}{c}\text { Mass } \\
(\mathbf{k g})\end{array}$ & $\begin{array}{c}\text { Tag } \\
\text { model }\end{array}$ & $\begin{array}{c}\text { Release } \\
\text { date }\end{array}$ & $\begin{array}{l}\text { Tracking } \\
\text { period } \\
\text { (days) }\end{array}$ & $\begin{array}{c}\text { Distance } \\
\text { from } \\
\text { released } \\
\text { point } \\
(\mathrm{km})\end{array}$ & $\begin{array}{l}\text { Bearing } \\
\text { from } \\
\text { released } \\
\text { point } \\
\left({ }^{\circ}\right)\end{array}$ & $\begin{array}{c}\text { Mean } \\
\text { travel } \\
\text { speed } \\
\left(\mathrm{km}_{1} \text {.day }\right. \\
1)\end{array}$ \\
\hline N1 & 171 & 69 & 44.7 & $A$ & $\begin{array}{c}\text { 19-Oct- } \\
10\end{array}$ & 244 & 4521 & 4 & 48 \\
\hline N2 & 51 & 64 & 29.6 & $A$ & $\begin{array}{c}\text { 12-Nov- } \\
10\end{array}$ & 182 & 3949 & 6 & 42 \\
\hline N3 & 199 & 66 & 40.3 & $B$ & $\begin{array}{c}\text { 23-Dec- } \\
10\end{array}$ & 134 & 3620 & 8 & 42 \\
\hline N4 & 215 & 54 & 29.3 & $B$ & $\begin{array}{c}\text { 28-Mar- } \\
11\end{array}$ & 126 & 3584 & 9 & 38 \\
\hline N5 & 338 & 61 & 26.5 & $D$ & $\begin{array}{c}\text { 15-Sep- } \\
11\end{array}$ & 219 & 4591 & 9 & 37 \\
\hline N6 & 238 & 73 & 50.2 & $A$ & $\begin{array}{c}\text { 23-Dec- } \\
10\end{array}$ & 101 & 2748 & 332 & 51 \\
\hline N7 & 876 & 72 & 54.4 & $A$ & $\begin{array}{c}\text { 23-Dec- } \\
10\end{array}$ & 144 & 3115 & 349 & 37 \\
\hline N8 & 143 & 69 & 36.4 & $B$ & $\begin{array}{c}\text { 29-Mar- } \\
11\end{array}$ & 141 & 3213 & 352 & 48 \\
\hline N9 & 44 & 61 & 28.5 & $D$ & $\begin{array}{c}\text { 16-Aug- } \\
11\end{array}$ & 260 & 3417 & 351 & 30 \\
\hline S1 & 470 & 64 & 33.4 & $C$ & $\begin{array}{c}\text { 14-Oct- } \\
09\end{array}$ & 48 & 1873 & 216 & 49 \\
\hline S2 & 212 & 68 & 44.0 & $B$ & $\begin{array}{c}\text { 23-Dec- } \\
10\end{array}$ & 157 & 2037 & 213 & 35 \\
\hline S3 & 141 & 71 & 50.0 & $D$ & $\begin{array}{c}\text { 16-Nov- } \\
11\end{array}$ & 394 & 2732 & 221 & 45 \\
\hline S4 & 332 & 65 & 32.4 & $D$ & $\begin{array}{c}\text { 11-Nov- } \\
11\end{array}$ & 401 & 3221 & 121 & 24 \\
\hline $\mathrm{X} 1$ & 453 & 77 & 58.7 & C & $\begin{array}{l}\text { 4-Mar- } \\
09\end{array}$ & 20 & 602 & 292 & 46 \\
\hline $\mathrm{X} 2$ & 28 & 67 & 37.2 & $C$ & $\begin{array}{c}\text { 11-Dec- } \\
09\end{array}$ & 59 & 348 & 249 & 31 \\
\hline X3 & 293 & 71 & 37.7 & $B$ & $\begin{array}{c}\text { 23-Dec- } \\
10\end{array}$ & 180 & 671 & 43 & 20 \\
\hline X4 & 224 & 71 & 54.2 & $A$ & $\begin{array}{c}\text { 17-Sep- } \\
10\end{array}$ & 171 & 1157 & 331 & 29 \\
\hline$\times 5$ & 557 & 73 & 55.0 & C & $\begin{array}{c}\text { 08-Oct- } \\
08\end{array}$ & 33 & 1107 & 357 & 41 \\
\hline
\end{tabular}


826 (5 tags) was not equipped with depth sensors.

\begin{tabular}{ccc} 
Recorded parameter & Model A and B & Model C \\
\hline \# of tags deployed & 10 & 4 \\
Dive duration $(\mathrm{s})$ & Single dive & Single dive \\
Dive depth $(\mathrm{m})$ & Single dive & - \\
Dive counter & $12 \mathrm{~h}$ & $24 \mathrm{~h}$ \\
Average dive duration $(\mathrm{m})$ & $12 \mathrm{~h}$ & $24 \mathrm{~h}$ \\
Maximum dive duration $(\mathrm{m})$ & $12 \mathrm{~h}$ & $24 \mathrm{~h}$ \\
Maximum dive depth $(\mathrm{m})$ & $12 \mathrm{~h}$ & - \\
Underwater percentage & $12 \mathrm{~h}$ & $24 \mathrm{~h}$ \\
Time-at-depth histograms & $12 \mathrm{~h}$ & $24 \mathrm{~h}$ \\
Dive qualification period & $5 \mathrm{~s}$ & $30 \mathrm{~s}$
\end{tabular}


Table 3 Distribution of diving parameters (median \pm IQR $(n)$ ) for 14 late juvenile loggerheads over the all tracking period (overall), depending on day time (Day and Night) and depending on behavioural modes (OT, OT, CT and CR). (CR: Coastal Residency, CT: Coastal Transit, OR: Oceanic Residency and OT: Oceanic Transit, Dss: Short and shallow dives, Ddl: Deep and long dives, Dsl: Deep and shallow dives)

Overall

\section{$300.3 \pm 117.3$}

(14)

$90.8 \pm 4.6(14)$

$114.7 \pm 18.6(10)$

$66.9 \pm 27.2(14)$

$8.5 \pm 4.9(14)$

$75.9 \pm 17.6(10)$

$75.9 \pm 17.6(10)$

$39.7 \pm 11.2(10)$

$15.4 \pm 11.7(10)$

$13.6 \pm 6(10)$

$7.8 \pm 3.9(10)$

$6.5 \pm 6.2(14)$
Night

OT

$215.1 \pm 100.4326 .4 \pm 128.5$

$356.3 \pm 81.3(10)$

$92.5 \pm 2.8(10)$

$88.6 \pm 27.8(10)$

$68.7 \pm 31.5(10)$

$6 \pm 3.8(10)$

$86.4 \pm 12.8(14)$

$64.6 \pm 47.2(10)$

$73 \pm 8.9(14)$

$85.2 \pm 28.2(10)$

$82.8 \pm 12.1(14)$

(14)

$91.6 \pm 4.5$ (14)

$139.1 \pm 40.9(10)$

$72.6 \pm 27.1$ (10)

$10.7 \pm 6(10)$

$126.7 \pm 17.5$ (10)

$65 \pm 28.1$ (14)

$7.9 \pm 4$ (14)

$53.5 \pm 19.1$ (10)

$6.2 \pm 8.3$ (10)

$8.2 \pm 5.9(10)$

$5.2 \pm 2.1$ (10)

$4.3 \pm 5.7$ (10)
$20.7 \pm 11.4(10)$

$21.8 \pm 14.3$ (10)

$19.3 \pm 9(10)$

$10.7 \pm 7(10)$

$5.2 \pm 5.7(10)$
$37.6 \pm 11.7$ (10)

$8.9 \pm 8.6(10)$

$15.1 \pm 6.9(10)$

$9.3 \pm 4.9(10)$

$6.4 \pm 5.8$ (14)
OR

CT

$405.5 \pm 175.4$

(13)

$268.5 \pm 38(4)$

$268 \pm 184.7(7)$

$80.7 \pm 15.3(7)$

$118.9 \pm 35.6(6)$

$80.5 \pm 47.7(7)$

$6.3 \pm 12(7)$

$109.3 \pm 22.6$

$57.7 \pm 18.6(13) \quad 56 \pm 29.1(4)$

$5.7 \pm 2.7(13) \quad 6.3 \pm 7(4)$

$86.6 \pm 8.4(14) \quad 76.4 \pm 4.9$ (4)

$79.3 \pm 28.2(10) \quad 65.5 \pm 15.2(4)$

$42.3 \pm 13.8(6)$

$8.8 \pm 15.1(6)$

$8.6 \pm 9(6)$

$5.7 \pm 3.6(6)$

$4.1 \pm 5.4(7)$
$43.2 \pm 8.1$ (9)

$5.5 \pm 3.1(9)$

$8.8 \pm 8.8(9)$

$8.1 \pm 2.7$ (9)

$6.5 \pm 6(13)$
$30.1 \pm 6(4)$

$25.8 \pm 13.1(4)$

$11.9 \pm 4.4$ (4)

$7.6 \pm 3.8(4)$

$4.6 \pm 5.5(4)$ 
832 Table 4 Distribution of oceanic parameters (median \pm IQR $(n)$ ) for the 833 three spatial groups: North, South and Undetermined; and for the 4 834 behavioral modes: Coastal Residency (CR), Coastal Transit (CT), 835 Oceanic Residency (OR) and Oceanic Transit (OT).

\begin{tabular}{cccc}
$\begin{array}{c}\text { Group / } \\
\text { Mode }\end{array}$ & SST $\left({ }^{\circ} \mathbf{C}\right)$ & NPP $\left(\mathbf{m g C ~ m}^{-2}\right.$ day $\left.^{-1}\right)$ & TKE $\left(\mathbf{m}^{2} \mathbf{~ s}^{-2}\right)$ \\
\hline North & $27.61 \pm 1.27(9)$ & $296.07 \pm 98.76(9)$ & $459.95 \pm 177.17(9)$ \\
South & $21.65 \pm 1.03(4)$ & $365.61 \pm 62.9(4)$ & $433.7 \pm 301.22(4)$ \\
Undetermined & $27.25 \pm 1.44(5)$ & $204.67 \pm 53.57(5)$ & $410.97 \pm 126.07(5)$ \\
OT & $27.05 \pm 2.39(18)$ & $261.92 \pm 80.62(18)$ & $448.98 \pm 202.46(18)$ \\
OR & $27.45 \pm 5.96(10)$ & $405.18 \pm 299.99(10)$ & $505.46 \pm 451.61(10)$ \\
CT & $27.16 \pm 1.64(18)$ & $208.11 \pm 58.8(18)$ & $294.64 \pm 288.41(18)$ \\
CR & $27.75 \pm 0.45(6)$ & $427.23 \pm 602.34(5)$ & $233.02 \pm 244.11(6)$
\end{tabular}




\section{ONLINE RESOURCE}

\section{Online Resource 1}

839 OR1. Fig. 1 Capture positions of loggerhead sea turtles by long-liners fisheries from Reunion Island 840 between 2007 and $2011(n=46)$. Black symbol show capture positions for individuals released with 841 a satellite tag.

842 OR1. Fig. 2 Time at depth histograms (Day (D) vs. Night (n)) of 10 late juvenile loggerhead sea 843 turtles. The subsurface layer $(<10 \mathrm{~m})$ is the most frequented during the day while turtles make more 844 usage of layers between 11 and $40 \mathrm{~m}$.

845 OR1. Fig.3 Time at depth histograms according to behavioral mode of 10 late juvenile loggerhead 846 sea turtles (OT: Oceanic Transit; OR: Oceanic Residency; CT: Coastal Transit; CR: Coastal 847 Residency). Turtles exhibit similar usage of the subsurface layer $(<10 \mathrm{~m})$ for all behavioral modes. 848 They made more usage of the 11-20 m layer during resident phases (OR and CR) but more usage of 849 the deepest layer ( $>40 \mathrm{~m}$ ) during the transit phases (OT and CT).

850 OR1. Fig. 4 Examples of tracks associated with oceanic eddies in the northern hemisphere for N5 (a) 851 and in the southern hemisphere for S2 (c) and S3 (c and d). (c) and (d) during an oceanic and resident 852 phase lasting 288 days, S3 clearly associated repeatedly with eddies in the Agulhas retroflection region at large of the South African coast. This constitutes the most striking example of association 854 with eddies observed in the Western Indian Ocean. Online Resource 2

857 Representation of individual's track and behavioral mode, time-at-depth distribution, and dive depth 858 distribution according to behavioral mode. 
859 Online Resource 3

860 Animations representing the distributions of oceanic environmental variables along track. 


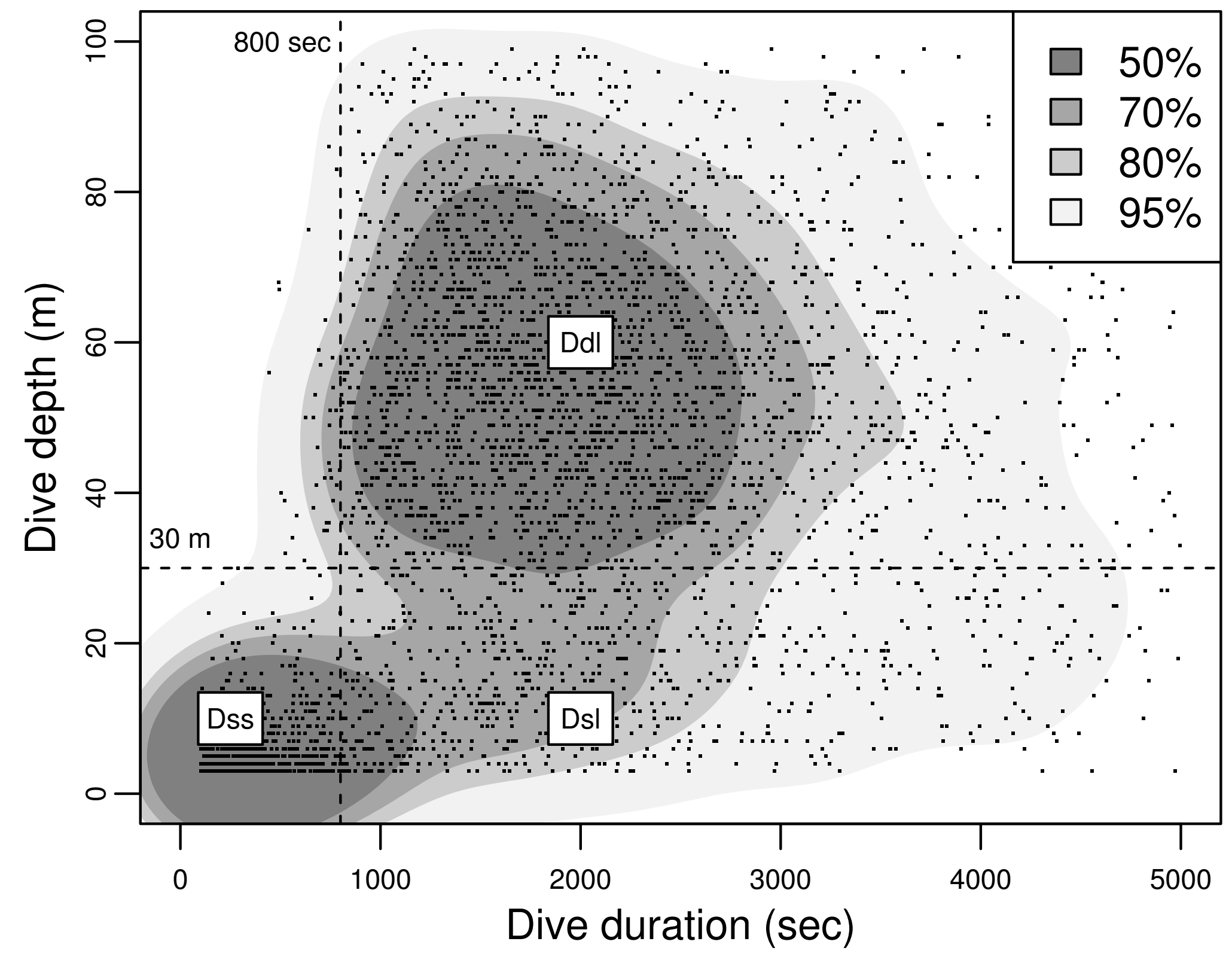


Fig. 2

Click here to download high resolution image

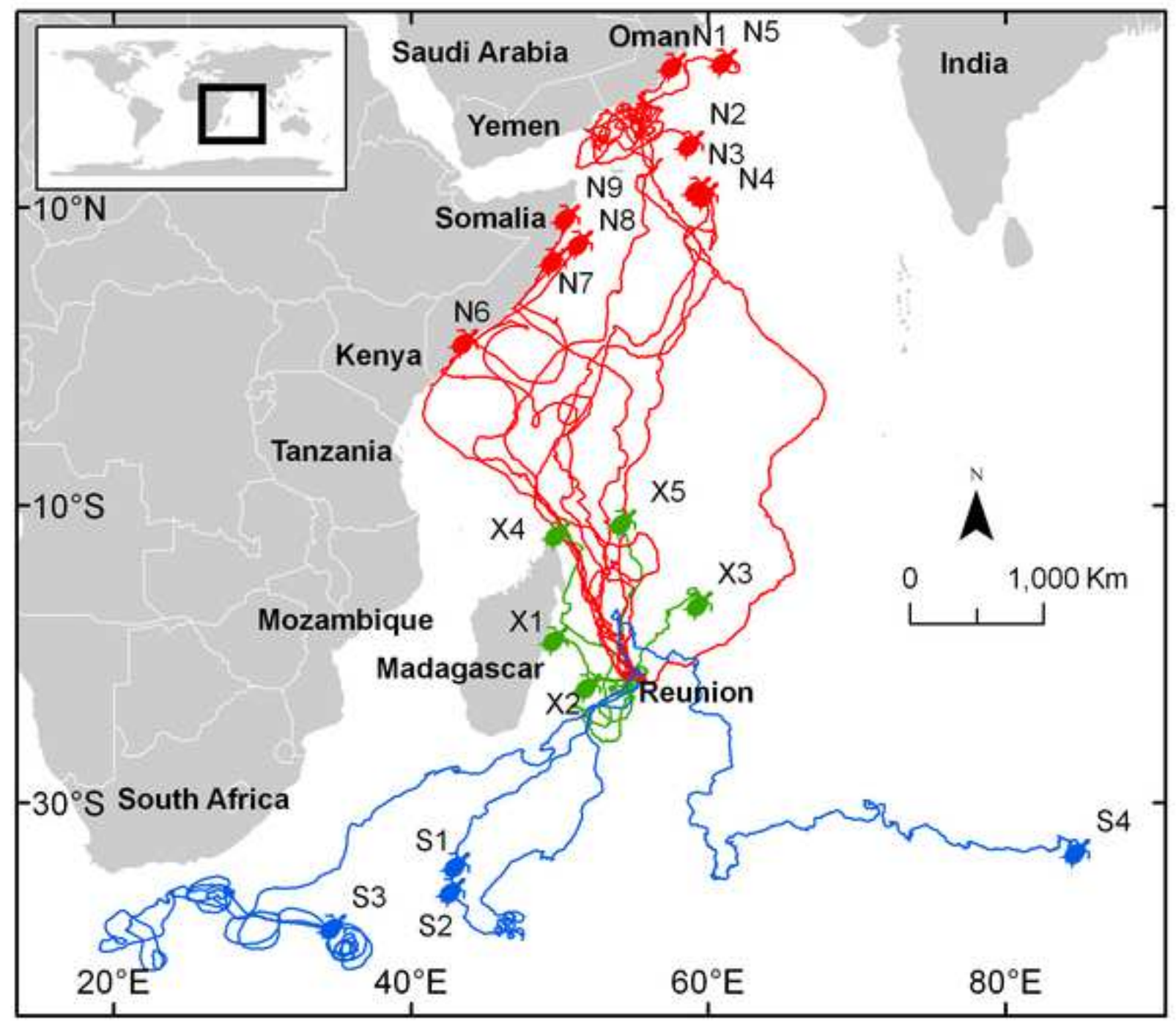




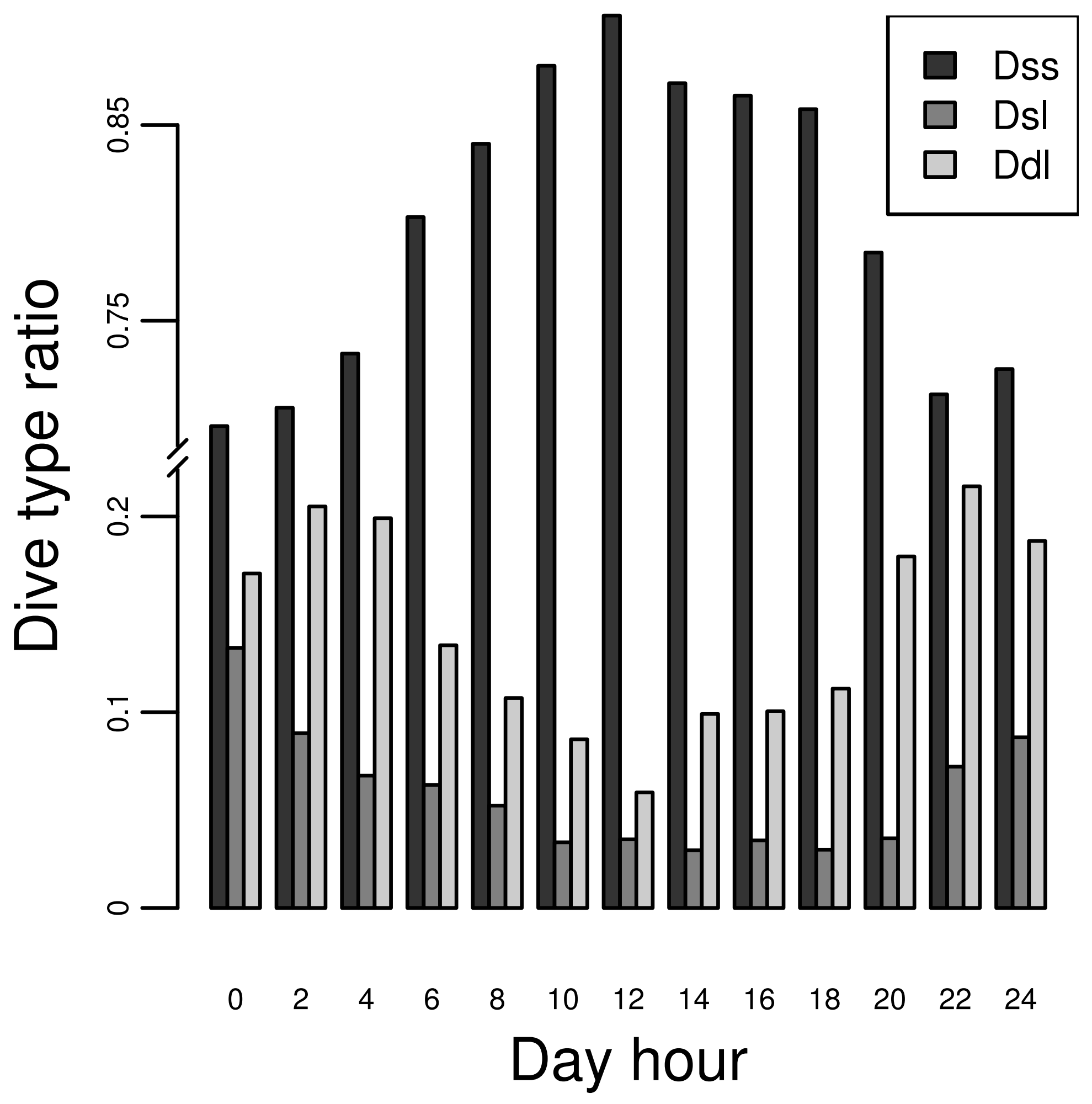


Fig. 5

Click here to download high resolution image
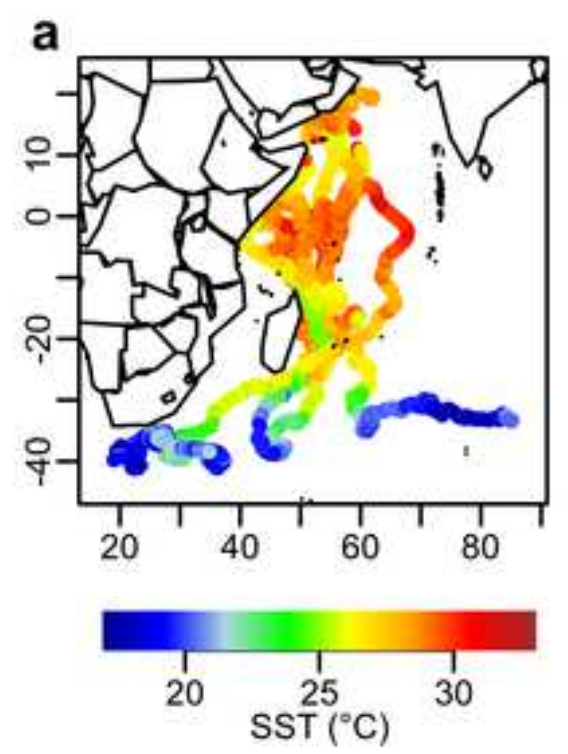

b
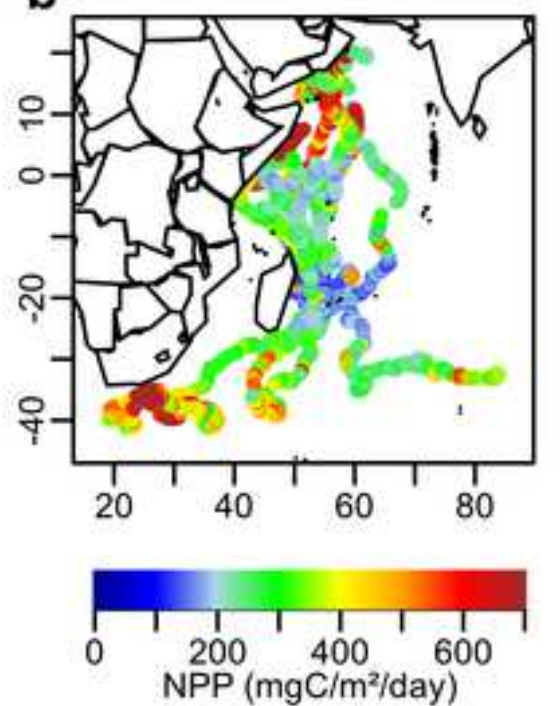

C
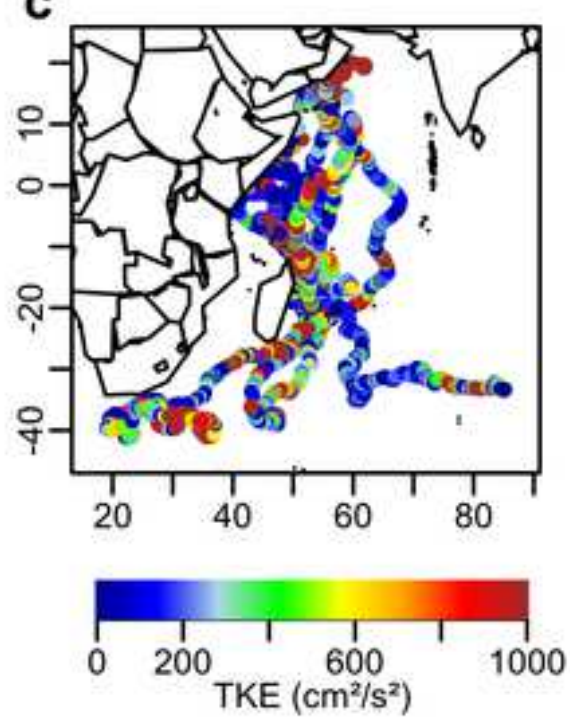
Fig. 6

a
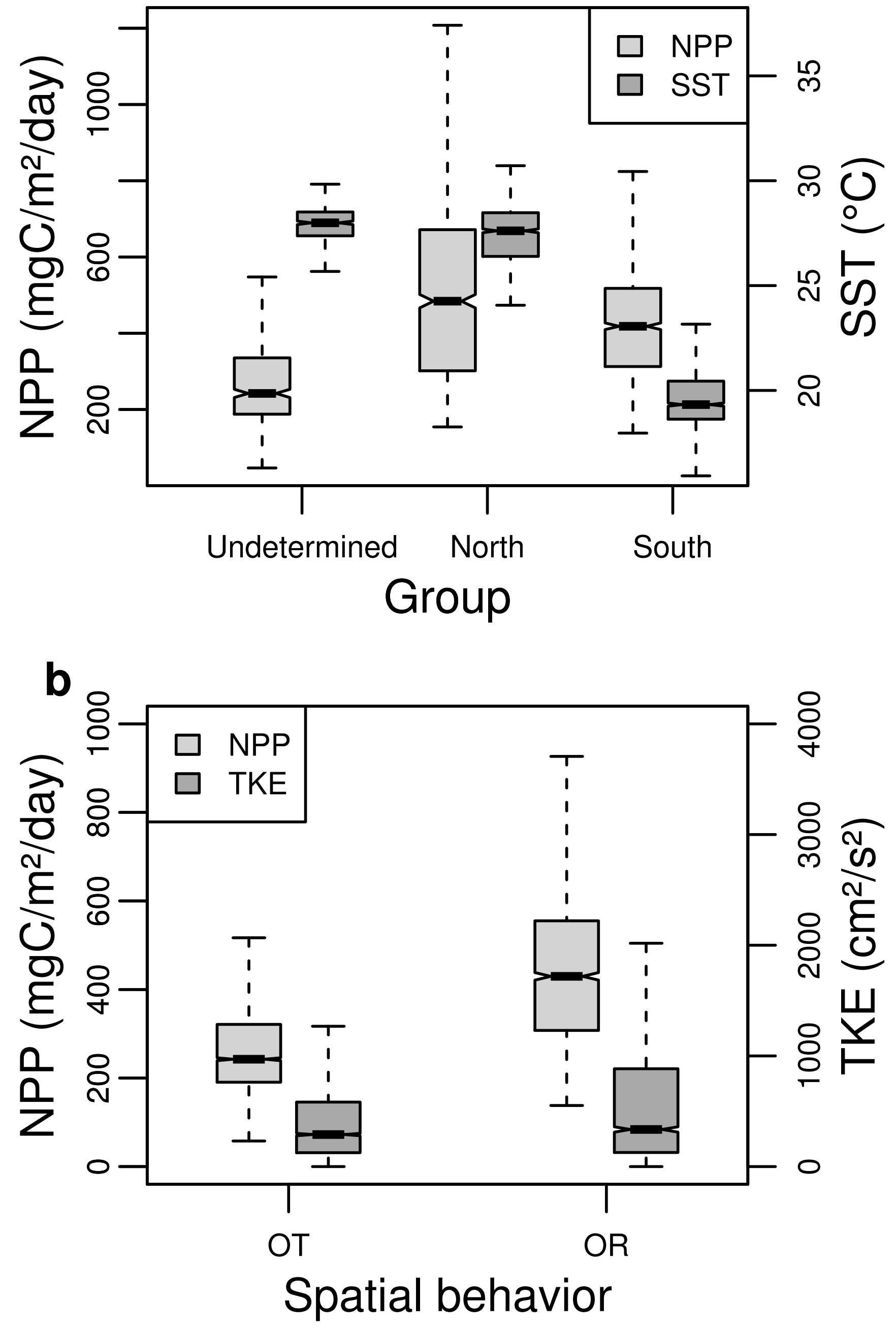